\title{
Sublingual Immunotherapy Tablet - a Cost-minimizing Alternative in the Treatment of Tree Pollen-induced Seasonal Allergic Rhinitis in Canada
}

Anne K. Ellis

Queens University

\section{Rémi Gagnon}

CHU de Quebec-Universite Laval

Eva Hammerby ( $\square$ ehbdk@alk.net )

ALK-Abello https://orcid.org/0000-0001-9418-264X

\section{Julia Shen}

PDCI Market Access Inc.

\section{Sheena Gosain}

PDCI Market Access Inc.

\section{Research Article}

Keywords: Cost-minimization, tree pollen, birch pollen, sublingual immunotherapy, allergy immunotherapy, allergic rhinitis

Posted Date: March 1st, 2021

DOI: https://doi.org/10.21203/rs.3.rs-254454/v1

License: (ㄷ) (i) This work is licensed under a Creative Commons Attribution 4.0 International License. Read Full License

Version of Record: A version of this preprint was published at Allergy, Asthma \& Clinical Immunology on July 8th, 2021. See the published version at https://doi.org/10.1186/s13223-021-00565-y. 


\section{Abstract}

Background: A cost-minimization analysis (CMA) was performed to evaluate the economic implications of introducing the SQ Tree sublingual immunotherapy (SLIT)-tablets marketed as ITULATEK ${ }^{\circledR}$ (Health Canada regulatory approval in April 2020) for the treatment of pollen-induced (birch, alder and/or hazel) seasonal allergic rhinitis in Canada (Ontario and Quebec), where Tree Pollen subcutaneous immunotherapy (SCIT) is already an available treatment option.

Methods: A CMA was deemed appropriate and was based on the assumption that the SQ Tree SLIT-tablets have comparable efficacy to Tree Pollen SCIT. A societal perspective was adopted in the model, including relevant costs of medications, costs of health care services, and productivity losses. The time horizon in the model was three years, which corresponds to a minimal treatment course of allergy immunotherapy. Resource use and costs were based on published sources, where available, and validated by Canadian specialist clinicians (allergists) in active practice in Ontario and in Quebec, where applicable. A discount rate of $1.5 \%$ was applied in accordance with the Canadian Agency for Drugs and Technologies in Health (CADTH) guidelines. To assess the robustness of the results, scenario analyses were performed by testing alternative assumptions for selected parameters (e.g., Tree Pollen SCIT resource use, discount rates, number of injections, annual SCIT dosing with maintenance injections, and nurse time support), to evaluate their impact on the results of the analysis.

Results: The direct costs, including the drug costs, physician and nursing services costs, for three years of treatment, were similar for both SQ Tree SLIT-tablets vs. Tree Pollen SCIT in both Ontario and Quebec $(\$ 2,799.01$ and $\$ 2,838.70$ vs. $\$ 2,813.41$ and $\$ 2771.81$, respectively). However, when the indirect costs (including patient's travel expenses and lost working hours) are included in the model, total savings for the treatment with SQ Tree SLIT-tablets of $\$ 1,691.44$ for Ontario and $\$ 1,705.63$ for Quebec were observed. Scenario analyses were conducted and showed that changes in assumptions continue to result in the savings of SQ Tree SLIT- tablets over Tree Pollen SCIT.

Conclusions: The CMA indicates that SQ Tree SLIT-tablets are a cost-minimizing alternative to Tree Pollen SCIT when considered from a societal perspective in Ontario and Quebec.

\section{Background}

Allergic rhinitis (AR) affects individuals worldwide with increasing prevalence. In Canada, AR is estimated to impact about 20 to $25 \%$ of the population, and more than half of these people are not well controlled on conventional medications [1]. Individuals suffer from a high symptom burden and associated consequences, which can have a considerable negative impact on patient productivity and quality of life, resulting in a substantial economic burden.

Tree pollen is one of the most common inhalant allergens that can cause AR, and birch pollen is the major tree pollen allergen across most of Canada [2]. The prevalence of allergic sensitization (skin test greater than 3 mm to any allergen) has been shown in the province of Saskatchewan to be as high as $32.1 \%$ for mixed grass and $26.8 \%$ for birch. In Edmonton, Alberta, the prevalence of positive skin test to grasses and birch has been shown to be $39.2 \%$ and $23.7 \%$, respectively $[3,4]$. The prevalence of atopic sensitization from 14 allergens in adults 20 to 44 years in six study sites across Canada (Vancouver, Winnipeg, Hamilton, Montreal, Halifax, and Prince Edward Island) found that, on average, the proportion of patients sensitized to birch pollen was $15.2 \%$ (95\% Cl 14.3 to 17.1) [5]. Individuals with birch pollen induced AR experience symptoms which may last several months each year due to the cross-reactivity of birch and related species. Immunological cross-reactivity between pollens from the birch homologous group (alder, hornbeam, hazel, oak, and beech) leads to individuals sensitized to birch pollen to also experience symptoms when exposed to pollen from related species [6, 7]. There is significant variation in pollen counts and season length across Canada due to geographic location and environmental factors which can change year to year based on climate $[3,5,8]$. Pollen data from 2016 to 2018 reported that the birch pollen season in Ontario and Quebec could last up to 7 weeks [8]. 
Several treatment options aimed to reduce the symptoms related to allergic rhinitis are available, including allergen avoidance, oral and intranasal antihistamines, intranasal corticosteroids, combination intranasal

corticosteroid/antihistamine sprays, and leukotriene receptor antagonists (LTRAs). For patients with persistent AR despite the use of pharmacologic therapies and evidence of specific IgE antibodies to clinically relevant allergens, allergy immunotherapy (AIT) is indicated [9-11]. AIT is either administered as subcutaneous immunotherapy (SCIT) via injections or as sublingual immunotherapy (SLIT) via tablets, both of which are approved in Canada. A typical treatment duration for AIT is 3 to 5 years; studies of AIT demonstrated that 3 years of continuous treatment with SCIT or SLIT produces a prolonged remission of symptoms [12].

The SQ Tree SLIT-tablets containing 12 SQ-Bet (a measure of the biological allergen activity based equally on the major allergen content (Bet $\vee 1$ ) and total allergenic activity) of standardized natural birch pollen extract of White Birch (Betula verrucosa) (ITULATEK $®$ ) are approved by Health Canada as an allergy immunotherapy for the treatment of moderate to severe seasonal allergic rhinitis, with or without conjunctivitis, induced by pollen from birch, alder and/or hazel [13]. The treatment is indicated in adults 18 to 65 years of age who have a clinical history of symptoms of AR, despite use of symptom-relieving medication, and a positive test of sensitization to one or more of the pollen of birch, alder or hazel (skin prick test and/or specific lgE).

The cost-minimization analysis (CMA) described here was performed to evaluate the economic implications of introducing SQ Tree SLIT-tablets in Canada, where Tree Pollen SCIT is already available as a treatment option.

\section{Methods}

\section{Cost minimization analysis:}

The CMA was used to estimate the economic impact of SQ Tree SLIT-tablets (B. verrucosa, 12 SQ-Bet, ALK, Denmark) compared with other AIT options, i.e. SCIT, available in Canada for the treatment of AR (with or without conjunctivitis) induced by birch tree, alder, and/or hazel pollen. Costs were collected and analysed for two provinces in Canada, Ontario and Quebec. Tree Pollen SCIT was identified as the only appropriate comparator for the analysis. A CMA was determined to be the most feasible and appropriate type of economic analysis due to the lack of availability of comparative efficacy and safety data for SQ Tree SLIT-tablets against Tree Pollen SCIT. The underlying assumption of therapeutic equivalence could be considered conservative given the evidence supporting a favourable safety profile for SLIT-tablets vs. SCIT [14-16]. Concomitant use of symptom-relieving medicines or other conventional medicines targeted to reduce symptoms of AR were assumed to be the same in SLIT-tablets and SCIT patients and have been excluded from the analysis. A societal perspective was adopted in the base case, including relevant costs of medications, health care services, travel, and productivity losses related to absenteeism, i.e., time off work. The time horizon in the analysis was three years, which corresponds to the minimum treatment course of AIT [12]. A discount rate of 1.5\% was applied in accordance with the Canadian Agency for Drugs and Technologies in Health (CADTH) guidelines for the Economic Evaluation of Health Technologies, and reflects common best practices for health economic modelling in Canada [17]. Inputs were sourced from literature and validated by Canadian specialist clinicians (allergists) in active practice in Ontario and in Quebec, respectively.

\section{Resource use:}

Three types of resources were considered in the analysis for each product: the medications themselves, health care resources, and patient resources. Table 1 presents an overview of the base case use of SQ Tree SLIT-tablets and Tree Pollen SCIT during a three-year course of AIT. 
Resource use for SQ Tree SLIT-tablets and Tree Pollen SCIT

\begin{tabular}{|c|c|c|c|c|c|c|c|c|c|c|c|c|}
\hline \multirow[t]{3}{*}{ Resource } & \multicolumn{6}{|c|}{ Ontario } & \multicolumn{6}{|c|}{ Quebec } \\
\hline & \multicolumn{3}{|c|}{$\begin{array}{l}\text { SQ Tree SLIT- } \\
\text { tablets }\end{array}$} & \multicolumn{3}{|c|}{ Tree Pollen SCIT } & \multicolumn{3}{|c|}{$\begin{array}{l}\text { SQ Tree SLIT- } \\
\text { tablets }\end{array}$} & \multicolumn{3}{|c|}{ Tree Pollen SCIT } \\
\hline & $\begin{array}{l}\text { Year } \\
1\end{array}$ & $2^{\text {Year }}$ & $\begin{array}{l}\text { Year } \\
3\end{array}$ & Year 1 & Year 2 & Year 3 & $\begin{array}{l}\text { Year } \\
1\end{array}$ & $2_{2}^{\text {Year }}$ & $\begin{array}{l}\text { Year } \\
3\end{array}$ & Year 1 & Year 2 & Year 3 \\
\hline $\begin{array}{l}10 \mathrm{~mL} \text { vial } \\
\text { (10 inj.) [18] }\end{array}$ & - & - & - & $1^{x}$ & $1^{x}$ & $1^{x}$ & - & - & - & $1^{x}$ & $1^{x}$ & $1^{x}$ \\
\hline $\begin{array}{l}\text { SQ Tree } \\
\text { SLIT-tablets }\end{array}$ & 180 & 180 & 180 & - & - & - & 180 & 180 & 180 & - & - & - \\
\hline $\begin{array}{l}\text { Number of } \\
\text { claims }\end{array}$ & 6 & 6 & 6 & - & - & - & 6 & 6 & 6 & - & - & - \\
\hline $\begin{array}{l}\text { Start-up } \\
\text { visits }\end{array}$ & 1 & 1 & 1 & - & - & - & 1 & 1 & 1 & - & - & - \\
\hline $\mathrm{GP}(5 \%) *$ & 0.05 & 0.05 & 0.05 & - & - & - & 0.05 & 0.05 & 0.05 & - & - & - \\
\hline $\begin{array}{l}\text { Specialist } \\
(95 \%)^{\star}\end{array}$ & 0.95 & 0.95 & 0.95 & - & - & - & 0.95 & 0.95 & 0.95 & - & - & - \\
\hline $\begin{array}{l}\text { Titration } \\
\text { visits (1 } \\
\text { week } \\
\text { between } \\
\text { inj.)* }\end{array}$ & - & - & - & 10 & 10 & 10 & - & - & - & 10 & 10 & 10 \\
\hline $\begin{array}{l}\text { GP (Ontario } \\
10 \% \text {, Quebec } \\
0 \%)^{\star}\end{array}$ & - & - & - & 1 & 1 & 1 & - & - & - & 0 & 0 & 0 \\
\hline $\begin{array}{l}\text { Specialist } \\
\text { (Ontario } \\
90 \% \text {, Quebec } \\
100 \%)^{*}\end{array}$ & - & - & - & 9 & 9 & 9 & - & - & - & 10 & 10 & 10 \\
\hline $\begin{array}{l}\text { Maintenance } \\
\text { visits ( } 4 \\
\text { weeks } \\
\text { between } \\
\text { inj..)* }\end{array}$ & - & - & - & 0 & 0 & 0 & - & - & - & 0 & 0 & 0 \\
\hline $\begin{array}{l}\text { Nurse time } \\
([\mathrm{h}], 0.5 \text { per } \\
\text { inj. })^{\star}\end{array}$ & - & - & - & 5 & 5 & 5 & - & - & - & 5 & 5 & 5 \\
\hline $\begin{array}{l}\text { Follow-up } \\
\text { visits }\end{array}$ & 1 & 1 & 1 & 1 & 1 & 1 & 1 & 1 & 1 & 1 & 1 & 1 \\
\hline $\begin{array}{l}\text { GP (Ontario } \\
\text { 10\% SLIT, } \\
\text { 20\% SCIT; } \\
\text { Quebec 0\%)* }\end{array}$ & 0.1 & 0.1 & 0.1 & 0.2 & 0.2 & 0.2 & 0 & 0 & 0 & 0 & 0 & 0 \\
\hline
\end{tabular}

Abbreviations: GP general practitioner, SCIT subcutaneous immunotherapy, inj. Injection, SQ Tree SLIT-tablets SQ tree pollen sublingual immunotherapy tablet

*Based on physician input, ${ }^{x}$ pre-seasonal: 1 treatment set, "Patient's time include: Travel time round trip 40 min. [18], preinjection wait time 15 min.*, injection time 5 min [18], post-injection wait time 30 min.*, physician consultation time 20 min. * ^Patient's time include: Travel time round trip $40 \mathrm{~min}$. [18], wait time $15 \mathrm{~min}$. [18], physician consultation time 20 min. [18], and for year 1 only a 30 min. post-tablet observational time after first tablet intake [18] 


\begin{tabular}{|c|c|c|c|c|c|c|c|c|c|c|c|c|}
\hline \multirow[t]{3}{*}{ Resource } & \multicolumn{6}{|c|}{ Ontario } & \multicolumn{6}{|c|}{ Quebec } \\
\hline & \multicolumn{3}{|c|}{$\begin{array}{l}\text { SQ Tree SLIT- } \\
\text { tablets }\end{array}$} & \multicolumn{3}{|c|}{ Tree Pollen SCIT } & \multicolumn{3}{|c|}{$\begin{array}{l}\text { SQ Tree SLIT- } \\
\text { tablets }\end{array}$} & \multicolumn{3}{|c|}{ Tree Pollen SCIT } \\
\hline & Year & $\begin{array}{l}\text { Year } \\
2\end{array}$ & $\begin{array}{l}\text { Year } \\
3\end{array}$ & Year 1 & Year 2 & Year 3 & Year & $2^{\text {Year }}$ & $\begin{array}{l}\text { Year } \\
3\end{array}$ & Year 1 & Year 2 & Year 3 \\
\hline $\begin{array}{l}\text { Specialist } \\
\text { (Ontario 90\% } \\
\text { SLIT, 80\% } \\
\text { SCIT; } \\
\text { Quebec } \\
\text { 100\%)* }\end{array}$ & 0.9 & 0.9 & 0.9 & 0.8 & 0.8 & 0.8 & 1 & 1 & 1 & 1 & 1 & 1 \\
\hline $\begin{array}{l}\text { Patient's } \\
\text { time }[h]^{*}[18]\end{array}$ & $3^{\wedge}$ & $3^{\wedge}$ & $3^{\wedge}$ & $19.58^{\#}$ & $19.58^{\#}$ & $19.58^{\#}$ & $3^{\wedge}$ & $3^{\wedge}$ & $3^{\wedge}$ & $20.42^{\#}$ & $20.42^{\#}$ & $20.42^{\#}$ \\
\hline $\begin{array}{l}\text { Patient's } \\
\text { travel } \\
\text { distance } \\
\text { ([km]; } 20 \mathrm{~km} \\
\text { per visit)* }\end{array}$ & 40 & 40 & 40 & 200 & 200 & 200 & 40 & 40 & 40 & 200 & 200 & 200 \\
\hline \multicolumn{13}{|c|}{$\begin{array}{l}\text { Abbreviations: GP general practitioner, SCIT subcutaneous immunotherapy, inj. Injection, SQ Tree SLIT-tablets SQ tree } \\
\text { pollen sublingual immunotherapy tablet }\end{array}$} \\
\hline \multicolumn{13}{|c|}{$\begin{array}{l}\text { *Based on physician input, }{ }^{x} \text { pre-seasonal: } 1 \text { treatment set, }{ }^{*} \text { Patient's time include: Travel time round trip } 40 \text { min. [18], pre- } \\
\text { injection wait time } 15 \text { min., injection time } 5 \text { min [18], post-injection wait time } 30 \text { min.*, physician consultation time } 20 \\
\text { min.* }{ }^{\star} \text { Patient's time include: Travel time round trip } 40 \text { min. [18], wait time } 15 \text { min. [18], physician consultation time } 20 \\
\text { min. [18], and for year } 1 \text { only a } 30 \text { min. post-tablet observational time after first tablet intake [18] }\end{array}$} \\
\hline
\end{tabular}

For the SQ Tree SLIT-tablets, the recommended dose is one tablet once daily (based on product monographs). As tree pollen is a seasonal allergen, it was assumed that the SQ Tree SLIT-tablets would be taken daily for 6 months, which includes both the pre-season and the tree pollen allergy season. For Tree Pollen SCIT, it was assumed that the treatment would be administered on a pre-seasonal basis with 10 weekly injections in the titration phase and no maintenance phase injections would be administered. It was also assumed that one $10 \mathrm{~mL}$ vial would last for 10 injections [18]. One treatment set was assumed to be sufficient for an entire pre-seasonal treatment schedule. The same treatment schedule assumptions were made for each year of treatment. The key difference between treatments is the at-home administration of the SQ Tree SLITtablets, resulting in lower health care resource use as well as lower patient resource use. In that respect, it was assumed that a SQ Tree SLIT-tablets patient would attend one start-up visit and one follow up visit during each year of analysis. Due to the daily at-home administrations, no further health care resource used was assumed to be associated with SLIT-tablets. It was assumed that Tree Pollen SCIT patients would receive 10 titration injections at a physician's clinic. A Tree-Pollen SCIT patient was also assumed to attend one follow-up visit per year. These assumptions are conservative as they do not include the health care costs related to adverse events and injection reactions to SCIT. Reactions could result in additional titration visits or, if a reaction is severe (e.g. anaphylaxis), a visit to a hospital emergency department may be necessary, resulting in additional health care resource use and costs.

\section{Resource costs:}

The costs of the resources are summarised in Table 2. Assumptions for medication costs were obtained from the manufacturer for SQ Tree SLIT-tablets, provincial formularies/manufacturer submitted price for SCIT, the Ontario Public Drug Programs $[19,20]$ and Régie de l'assurance maladie du Québec (RAMQ) [21]. Dispensing fees of \$8.83 and \$9.28 were applied for each claim of the SQ Tree SLIT-tablets for Ontario and Quebec, respectively [20, 22]. Pharmacy and wholesaler mark-up percentages were not included in this analysis. Costs for the health care services were obtained from the Ontario Schedule of Benefits [23], Manuel des Médécins Omnipracticiens [24], and Living in Canada (Canadian Registered Nurse 
salary) [25,26]. Cost estimates for hours of lost work were obtained from Statistics Canada [27], and travel costs per kilometre were obtained from the Government of Canada 2020 Reasonable Allowance Rates [28]. All costs were presented in Canadian Dollars.

Table 2

Resource costs for SQ Tree SLIT-tablets and Tree Pollen SCIT

\begin{tabular}{|c|c|c|c|c|}
\hline \multirow{2}{*}{$\begin{array}{l}\text { Cost } \\
\text { category }\end{array}$} & \multicolumn{2}{|l|}{ Cost type } & \multicolumn{2}{|c|}{$\$ C A D /$ unit } \\
\hline & Ontario & Quebec & Ontario & Quebec \\
\hline \multirow{2}{*}{$\begin{array}{l}\text { SQ Tree } \\
\text { SLIT- } \\
\text { tablets }\end{array}$} & \multicolumn{2}{|l|}{ Box of 30 tablets } & \multicolumn{2}{|l|}{132.00} \\
\hline & \multicolumn{2}{|l|}{ Dispensing fee/claim $[20,36]$} & 8.83 & 9.28 \\
\hline \multirow{2}{*}{$\begin{array}{l}\text { Tree } \\
\text { Pollen } \\
\text { SCIT } \\
\text { vials }\end{array}$} & \multicolumn{2}{|c|}{$\begin{array}{l}\text { Pre-Seasonal Treatment: Presaisonnier- Arbres Complete Treatment [Allegro - } \\
\text { 99101142] (one treatment) [21] }\end{array}$} & \multicolumn{2}{|l|}{265.00} \\
\hline & \multicolumn{4}{|c|}{$\begin{array}{l}\text { Annual Treatment - } 10 \mathrm{~mL} \text { concentrate - Monovalent standardise [Allegro - } \\
\text { 99101107] (one vial) [21] }\end{array}$} \\
\hline \multirow[t]{4}{*}{ Physician } & $\begin{array}{l}\text { Medical specific re-assessment } \\
\text { (follow-up visit), specialist } \\
\text { consultation, A474 [22] }\end{array}$ & $\begin{array}{l}\text { Initial visit, under } 80 \text {, In office or at home, less } \\
\text { than } 500 \text { patients (average) - Code } 15801 \text { [23] }\end{array}$ & 63.70 & 75.13 \\
\hline & $\begin{array}{l}\text { Partial assessment (pre- or post- } \\
\text { injection), specialist consultation, } \\
\text { A478 [22] }\end{array}$ & $\begin{array}{l}\text { Follow-up visit, under } 80 \text {, In office or at home, } \\
\text { less than } 500 \text { patients (average) - Code } 15803 \\
\text { [23] }\end{array}$ & 38.25 & 37.55 \\
\hline & $\begin{array}{l}\text { Injection (sole reason for visit), } \\
\text { G202 [22] }\end{array}$ & \multirow{2}{*}{$\begin{array}{l}\text { Hyposensitization treatment, without } \\
\text { examination, one or more injections in same } \\
\text { session - Code } 00400 \text { [23] }\end{array}$} & 4.45 & \multirow[t]{2}{*}{5.10} \\
\hline & $\begin{array}{l}\text { Injection (with consultation at } \\
\text { same visit), G212 [22] }\end{array}$ & & 9.75 & \\
\hline Nurse & Hourly wage $[24,25]$ & & 39.22 & 34.22 \\
\hline \multirow[t]{2}{*}{ Patient } & \multicolumn{2}{|l|}{ Average hourly wage [26] } & 28.52 & 29.01 \\
\hline & \multicolumn{2}{|l|}{ Travel expense by private car [27] } & \multicolumn{2}{|l|}{0.59} \\
\hline
\end{tabular}

To calculate the costs and potential savings associated with the use of SQ Tree SLIT-tablets vs. Tree Pollen SCIT over the three-year time horizon, the cost per unit of each resource was multiplied by the amount of resource used each year. For Tree Pollen SCIT, the base case assessed the costs and resource use for pre-seasonal treatment while a scenario analysis considered the costs and resource use for annual treatment.

\section{Scenario analyses:}

To assess the robustness of the results and the impact of assumptions on the results of the analysis, scenario analyses were performed. Alternative assumptions for parameters such as Tree Pollen SCIT resource use, discount rates, number of injections, annual SCIT dosing with maintenance injections, and nurse time support were considered.

\section{Results}

\section{Cost of treatment - SQ Tree SLIT-tablets vs. Tree Pollen SCIT}


The annual costs of treatment and the results of potential savings associated with the use of three-year treatment with SQ Tree SLIT-tablets vs. Tree Pollen SCIT are summarised in Table 3 and Table 4, respectively. The annual cost per treatment for each of the three years are the same for both SQ Tree SLIT-tablets vs. Tree Pollen SCIT: for SQ Tree SLIT-tablets, \$1,056.09 in Ontario and \$1,070.99 in Quebec, and for Tree Pollen SCIT, \$1,628.32 in Ontario and \$1,648.01 in Quebec (Table 3). The direct costs, including the drug costs, physician and nurse services, for a three-year treatment period were similar for both treatments for both Ontario and Quebec: for SQ Tree SLIT-tablets \$2,799.01 and \$2,838.70, respectively, and for Tree Pollen SCIT \$2,813.41 and \$2771.81, respectively (Table 4). The indirect costs, including patient's travel expenses and hours lost from paid labour, were higher for Tree Pollen SCIT for both Ontario and Quebec: for SQ Tree SLIT-tablets \$322.66 and $\$ 327.01$, respectively, and for Tree Pollen SCIT \$1,999.70 and \$2.099.53, respectively. Overall, the CMA revealed total savings for the treatment with SQ Tree SLIT-tablets of $\$ 1,691.44$ for Ontario and $\$ 1,705.63$ for Quebec over the three-year analysis period (Table 4). 
Table 3

Costs of SQ Tree SLIT-tablets and Tree Pollen SCIT treatment per year (in \$ CAD)

\begin{tabular}{|c|c|c|c|c|c|c|}
\hline \multirow[t]{2}{*}{ Cost category } & \multicolumn{3}{|l|}{ Ontario } & \multicolumn{3}{|l|}{ Quebec } \\
\hline & Year 1 & Year 2 & Year 3 & Year 1 & Year 2 & Year 3 \\
\hline \multicolumn{7}{|l|}{ SQ Tree SLIT-tablets } \\
\hline Drug costs & 844.98 & 844.98 & 844.98 & 847.68 & 847.68 & 847.68 \\
\hline Tablet costs & 792.00 & 792.00 & 792.00 & 792.00 & 792.00 & 792.00 \\
\hline Dispensing fee & 52.98 & 52.98 & 52.98 & 55.68 & 55.68 & 55.68 \\
\hline Physician costs & 101.95 & 101.95 & 101.95 & 112.68 & 112.68 & 112.68 \\
\hline GP costs & 8.28 & 8.28 & 8.28 & 1.88 & 1.88 & 1.88 \\
\hline Specialists costs & 93.67 & 93.67 & 93.67 & 110.80 & 110.80 & 110.80 \\
\hline Total Health care costs & 946.93 & 946.93 & 946.93 & 960.36 & 960.36 & 960.36 \\
\hline Patients costs & 109.16 & 109.16 & 109.16 & 110.63 & 110.63 & 110.63 \\
\hline Time costs & 85.56 & 85.56 & 85.56 & 87.03 & 87.03 & 87.03 \\
\hline Travel costs & 23.60 & 23.60 & 23.60 & 23.60 & 23.60 & 23.60 \\
\hline Total costs & $1,056.09$ & $1,056.09$ & $1,056.09$ & $1,070.99$ & $1,070.99$ & $1,070.99$ \\
\hline \multicolumn{7}{|l|}{ Tree Pollen SCIT } \\
\hline Drug costs & 265.00 & 265.00 & 265.00 & 265.00 & 265.00 & 265.00 \\
\hline Physician costs & 490.70 & 490.70 & 490.70 & 501.63 & 501.63 & 501.63 \\
\hline Injection & 44.50 & 44.50 & 44.50 & 51.00 & 51.00 & 51.00 \\
\hline GP costs & 4.45 & 4.45 & 4.45 & 0.00 & 0.00 & 0.00 \\
\hline Specialists costs & 40.05 & 40.05 & 40.05 & 51.00 & 51.00 & 51.00 \\
\hline Consultation costs & 446.20 & 446.20 & 446.20 & 450.63 & 450.63 & 450.63 \\
\hline GP costs & 50.99 & 50.99 & 50.99 & 0.00 & 0.00 & 0.00 \\
\hline Specialists costs & 395.21 & 395.21 & 395.21 & 450.63 & 450.63 & 450.63 \\
\hline Nurse costs & 196.10 & 196.10 & 196.10 & 171.10 & 171.10 & 171.10 \\
\hline Total Health care costs & 951.80 & 951.80 & 951.80 & 937.73 & 937.73 & 937.73 \\
\hline Patients costs & 676.52 & 676.52 & 676.52 & 710.29 & 710.29 & 710.29 \\
\hline Time costs & 558.52 & 558.52 & 558.52 & 592.29 & 592.29 & 592.29 \\
\hline Travel costs & 118.00 & 118.00 & 118.00 & 118.00 & 118.00 & 118.00 \\
\hline Total costs & $1,628.32$ & $1,628.32$ & $1,628.32$ & $1,648.01$ & $1,648.01$ & $1,648.01$ \\
\hline
\end{tabular}


Table 4

Costs and potential savings: three-year treatment SQ Tree SLIT-tablets vs. Tree Pollen SCIT (in SCAD)

\begin{tabular}{|c|c|c|c|c|c|c|}
\hline \multirow[t]{3}{*}{ Cost category } & \multicolumn{3}{|l|}{ Ontario } & \multicolumn{3}{|l|}{ Quebec } \\
\hline & $\begin{array}{l}\text { SQ Tree SLIT- } \\
\text { tablets }\end{array}$ & $\begin{array}{l}\text { Tree Pollen } \\
\text { SCIT }\end{array}$ & $\begin{array}{l}\text { SQ Tree SLIT- } \\
\text { tablets }\end{array}$ & $\begin{array}{l}\text { SQ Tree SLIT- } \\
\text { tablets }\end{array}$ & $\begin{array}{l}\text { Tree Pollen } \\
\text { SCIT }\end{array}$ & $\begin{array}{l}\text { SQ Tree SLIT- } \\
\text { tablets }\end{array}$ \\
\hline & & & $\begin{array}{l}\text { vs. Tree Pollen } \\
\text { SCIT }\end{array}$ & & & $\begin{array}{l}\text { vs. Tree Pollen } \\
\text { SCIT }\end{array}$ \\
\hline Drug costs & $2,497.66$ & 783.31 & $1,714.35$ & $2,505.64$ & 783.31 & $1,722.33$ \\
\hline Physician costs & 301.35 & $1,450.45$ & $-1,149.10$ & 333.05 & $1,482.75$ & $-1,149.69$ \\
\hline Nurse costs & - & 579.65 & -579.65 & - & 505.75 & -505.75 \\
\hline $\begin{array}{l}\text { Total health care } \\
\text { costs }\end{array}$ & $2,799.01$ & $2,813.41$ & -14.40 & $2,838.70$ & $2,771.81$ & 66.89 \\
\hline $\begin{array}{l}\text { Indirect costs } \\
\text { (patient) }\end{array}$ & 322.66 & $1,999.70$ & $-1,677.04$ & 327.01 & $2,099.53$ & $-1,772.52$ \\
\hline Total costs & $3,121.68$ & $4,813.11$ & $-1,691.44$ & $3,165.71$ & $4,871.33$ & $-1,705.63$ \\
\hline
\end{tabular}

\section{Scenario analyses}

Results of the scenario analyses are shown in Fig. 1. Overall, the scenario analyses demonstrated cost savings with SQ Tree SLIT-tablet treatment compared with Tree Pollen SCIT for each of the scenarios analysed, with some variation in the magnitude of potential savings. Results for the cost difference for treatment over three years with SQ Tree SLIT-tablets compared with Tree Pollen SCIT were sensitive to changes in nurse time per SCIT injection, treatment schedule (annual vs. seasonal for SCIT, longer birch season for SLIT-tablets) and number of SCIT pre-season injections. When the nurse time was reduced from 30 to 15 minutes, the potential savings with SQ Tree SLIT-tablets vs. Tree Pollen SCIT shifted to $\$ 1,401.61$ for Ontario and $\$ 1,452.75$ for Quebec over the three-year analysis period. An increase in nurse time to 45 minutes resulted in potential savings of $\$ 1,981.26$ and $\$ 1,958.50$ over the three-year analysis period, respectively. The most significant cost difference between SQ Tree SLIT-tablets and Tree Pollen SCIT treatment was observed for the scenario of annual treatment with SCIT. Annual treatment is common in clinical practice and the schedule comprises of sixteen weekly titration visits followed by a maintenance visit every four weeks, for the remaining duration of three years of therapy. This analysis resulted in potential savings, for the SLIT-tablets, of $\$ 6,579.98$ for Ontario and $\$ 6,742.21$ for Quebec over the three-year analysis period. The least potential savings were observed for the scenario that assessed a longer birch season ( 9 vs. 6 months of SLIT-tablets treatment) with projected cost savings for the SLIT-tablets of \$442.60 (Ontario) and 452.80 (Quebec). Compared to the base case, almost no impact to costs were observed if the discount rate was changed (from $1.5 \%$ to either $0 \%$ or $3 \%$ ) in the scenario analyses.

\section{Discussion}

The current CMA analysed the economic impact of SQ Tree SLIT-tablets compared with Tree Pollen SCIT in Canada for the treatment of tree pollen-induced AR assuming a three year treatment schedule. Overall, the results indicate a cost-minimizing potential of SQ Tree SLIT-tablets for the treatment of tree pollen-induced AR when compared with Tree Pollen SCIT. This result was consistent for all scenarios analysed. When comparing only the direct costs, treatment with SQ Tree SLIT-tablets and Tree Pollen SCIT were similar for both Ontario and Quebec. The higher drug costs for SQ Tree SLIT-tablets vs. Tree Pollen SCIT (\$2,497.66 vs. \$783.31 for Ontario, \$2,505.64 vs. \$783.31 for Quebec) were offset by the healthcare resource 
costs of physician and nurse services, which were more than three times higher for Tree Pollen SCIT. Comparing the indirect costs, these are much higher for Tree Pollen SCIT than SQ Tree SLIT-tablets due to more frequent visits for administrations by health care professionals. Subsequently, when assessing total costs, which resulted in overall potential savings of $\$ 1,691.44$ for Ontario and $\$ 1,705.63$ for Quebec, the CMA indicates that treatment with SQ Tree SLIT-tablets is a costminimizing alternative to Tree Pollen SCIT in Canada. This is in line with a recent analysis [29], which reported that in four of six studies comparing cost outcomes of SLIT vs. SCIT, SLIT was the cost-saving therapy.

As Tree Pollen SCIT treatment requires a much higher number of clinic visits, this subsequently results in both higher costs associated with health care professional services and patient resources, thus outweighing the higher drug costs for the SQ Tree SLIT-tablets. With the difference in the number of clinic visits between SQ Tree SLIT-tablets and Tree Pollen SCIT treatment being the main driver of the cost difference, parameters related to the treatment setting had a relatively large impact in the scenario analyses. For example, the most significant savings were obtained in comparison with the annual treatment administration regimen for Tree Pollen-SCIT with the potential of SQ Tree SLIT-tablets to reduce healthcare resource use and associated costs significantly. In addition, at-home administration of SQ Tree SLIT-tablets is more convenient for patients as it decreases the burden of travel and time-off work. At-home administration of SLIT can be particularly advantageous in rural communities, where large distances from the nearest clinic may pose additional barriers to access. With a high number of visits accompanied by a high time load required for SCIT, adherence to treatment could be potentially reduced. Time load of AIT was previously identified as a central factor for patients to ensure optimal adherence to therapy [30]. This is also supported by a patient preference study conducted in Germany using a discrete choice experiment in 239 adults with moderate to severe grass, birch, and/or house dust mite AR. The study found that the attribute most preferred by patients regarding the mode of AIT administration was related to the number and duration of physician visits, with a strong preference for fewer visits with shorter durations [31]. A parallel physician patient survey found that Canadian patients, when asked about their preference for AIT options, were more likely to follow their allergists' recommendation for initiation of SLIT compared with SCIT [32]. Positive effects on patients' quality of life have been demonstrated in the pivotal phase III trial for SQ Tree SLIT-tablets during both the birch and tree pollen season [33]. Assessed by the Rhinoconjunctivitis Quality of Life Questionnaire (RQLQ), the SQ tree SLIT-tablets showed a significantly better overall RQLQ than placebo with relative differences of $31 \%$ for the birch pollen season and $28 \%$ for the tree pollen season (both seasons $P<$.0001) [33]. Furthermore, the convenient at-home administration of SLIT-tablets not only frees up health care resources that could be used to help more patients in need of AIT treatment but also reduces public contact events which is favourable in circumstances such as the COVID-19 global pandemic.

The CMA has some limitations. A CMA builds on an assumption of equal efficacy. Given the lack of head-to-head studies, this assumption is a limitation of this analysis. However, a CMA was determined to be the most feasible and appropriate type of economic analysis, as this assessment method has also been used in similar studies [34-36]. Costs and resource use included in the analysis were solely associated with the treatments and treatment administration, including direct and indirect costs. Other potential aspects related to tree pollen-induced AR were not considered. In addition, certain resource use assumptions were based on input from Canadian allergy specialists in clinical practice in Ontario and Quebec, and there might be geographical and regional variations in resource use in clinical practice.

\section{Conclusions}

The CMA estimates the SQ Tree SLIT-tablets to be a cost-minimizing alternative to Tree Pollen SCIT for the treatment of tree pollen induced AR when considered from a societal perspective in both Ontario and Quebec. Scenario analyses which varied resource use, discount rates, number of injections, nurse time, treatment schedule (annual vs. seasonal for SCIT, longer birch season for SLIT-tablets) support this conclusion. All analysed scenarios resulted in savings when treating with SQ Tree SLITtablets compared to Tree Pollen SCIT. This CMA demonstrates the cost savings to society associated with introducing SQ Tree SLIT-tablets in Canada. 


\section{List Of Abbreviations}

AIT allergy immunotherapy

AR allergic rhinitis

Bet Betula (from Betula verrucosa)

CADTH Canadian Agency for Drugs and Technologies in Health

CMA cost minimization analysis

IG Immunglobulin

LTRA leukotriene receptor antagonist

RAMQ Régie de l'assurance maladie du Québec

SCIT subcutaneous immunotherapy

SLIT sublingual immunotherapy

\section{Declarations}

\section{Authors' contributions}

AKE and RG validated the inputs, sourced from literature, into the model. JS and SG developed the model. EH provided study oversight and contributed to the study design and analyses. All authors were contributors in writing the manuscript, read and approved the final manuscript.

\section{Acknowledgements}

Manuscript writing support was provided by Wiebke Griemberg, PhD from TFS Trial Form Support GmbH and Michael Bachmann, Copentown Healthcare Consulting with financial support provided by ALK-Abello.

\section{Competing interests}

AKE (over her lifetime) has participated in advisory boards for Abbvie, ALK-Abello, Aralez, Circassia Ltd, GlaxoSmithKline, LEO Pharma, Merck, Mylan, Novartis, Pediapharm, Pfizer and Sanofi and has been a speaker for ALK-Abello, Aralez, AstraZeneca, Boehringer Ingelheim, Meda, Medexus, Merck, Mylan, Novartis, Pediapharm, Pfizer, and Takeda. Her institution has received research grants from ALK Abello, Aralez, AstraZeneca, Bayer, Circassia Ltd, Green Cross Pharmaceuticals, GlaxoSmithKline, Medexus, Sun Pharma, Merck, Novartis, Pfizer, Regeneron and Sanofi. AKE is also a former consultant to ALK-Abello Canada and Bayer Consumer Health Division.

EH is an employee of ALK-Abello.

JS and SG are employees of PDCI, and PDCI has performed consulting work for ALK-Abello.

RG has participated in advisory boards for ALK-Abello, GlaxoSmithKline, Merck, Novartis, Pediapharm, Pfizer, AstraZeneca, Aralez, Shire, CSL Behring and Sanofi and has been a speaker for ALK-Abello, Aralez, AstraZeneca, Merck, Novartis, Pediapharm and Pfizer. RG is also involved in clinical trials with Green Cross Pharmaceuticals, GlaxoSmithKline, Merck, Novartis, AstraZeneca, DBV, Regeneron, Stallergenes, Shire, Biocryst and Sanofi. 
The data collected and analysed during the current study are available from the corresponding author on reasonable request.

\section{Consent for publication}

Not applicable. No individual patient data is provided.

\section{Ethics approval and consent to participate}

Ethical clearance and consent to participate are not applicable to this article.

\section{Funding}

This study was supported by ALK-Abello.

\section{References}

1. Keith PK, Desrosiers M, Laister T, Schellenberg RR, Waserman S. The burden of allergic rhinitis (AR) in Canada: perspectives of physicians and patients. Allergy Asthma Clin Immunol Off J Can Soc Allergy Clin Immunol. 2012;8:7.

2. White JF, Bernstein DI. Key pollen allergens in North America. Ann Allergy Asthma Immunol Off Publ Am Coll Allergy Asthma Immunol. 2003;91:425-35; quiz 435-6, 492.

3. Lok SD, Davis BE, Cockcroft DW. Prevalence of allergen sensitization in 1000 adults in Saskatchewan. Allergy Asthma Clin Immunol. 2017;13:9.

4. Ahmed $\mathrm{H}$, Ospina MB, Sideri K, Vliagoftis $\mathrm{H}$. Retrospective analysis of aeroallergen's sensitization patterns in Edmonton, Canada. Allergy Asthma Clin Immunol Off J Can Soc Allergy Clin Immunol. 2019;15:6.

5. Chan-Yeung M, Anthonisen NR, Becklake MR, Bowie D, Sonia Buist A, Dimich-Ward H, et al. Geographical variations in the prevalence of atopic sensitization in six study sites across Canada. Allergy. 2010;65:1404-13.

6. Couroux P, Ipsen H, Stage BS, Damkjær JT, Steffensen MA, Salapatek AM, et al. A birch sublingual allergy immunotherapy tablet reduces rhinoconjunctivitis symptoms when exposed to birch and oak and induces IgG4 to allergens from all trees in the birch homologous group. Allergy. 2019;74:361-9.

7. Biedermann T, Winther L, Till SJ, Panzner P, Knulst A, Valovirta E. Birch pollen allergy in Europe. Allergy. 2019;74:123748.

8. Aerobiology Research Laboratories. Pollen forecasts and collection stations 2020. [Internet]. Available from: https://www.pollenexperts.ca/monitoring-network/. Accessed Feb12, 2020

9. Small P, Keith PK, Kim H. Allergic rhinitis. Allergy Asthma Clin Immunol Off J Can Soc Allergy Clin Immunol [Internet]. 2018 [cited 2018 Oct 9];14. Available from: https://www.ncbi.nlm.nih.gov/pmc/articles/PMC6156899/

10. Wallace DV, Dykewicz MS, Bernstein DI, Blessing-Moore J, Cox L, Khan DA, et al. The diagnosis and management of rhinitis: an updated practice parameter. J Allergy Clin Immunol. 2008;122:S1-84.

11. Brożek JL, Bousquet J, Agache I, Agarwal A, Bachert C, Bosnic-Anticevich S, et al. Allergic Rhinitis and its Impact on Asthma (ARIA) guidelines-2016 revision. J Allergy Clin Immunol. 2017;140:950-8.

12. Jutel M, Agache I, Bonini S, Burks AW, Calderon M, Canonica W, et al. International consensus on allergy immunotherapy. J Allergy Clin Immunol. 2015;136:556-68.

13. ALK-Abelló A/S. ITULATEK ${ }^{T M}$ (Standardized Allergen Extract, White Birch (Betula Verrucosa)) product monograph. Hørsholm, Denmark. 2020.

14. Epstein TG, Liss GM, Murphy-Berendts K, Bernstein DI. Immediate and delayed-onset systemic reactions after subcutaneous immunotherapy injections: ACAAI/AAAAI surveillance study of subcutaneous immunotherapy: year 2. Ann Allergy Asthma Immunol Off Publ Am Coll Allergy Asthma Immunol. 2011;107:426-431.e1. 
15. Demoly P, Emminger W, Rehm D, Backer V, Tommerup L, Kleine-Tebbe J. Effective treatment of house dust mite-induced allergic rhinitis with 2 doses of the SQ HDM SLIT-tablet: Results from a randomized, double-blind, placebo-controlled phase III trial. J Allergy Clin Immunol. 2016;137:444-451.e8.

16. Bernstein DI, Wanner M, Borish L, Liss GM, the Immunotherapy Committee of the American Academy of Allergy A and I. Twelve-year survey of fatal reactions to allergen injections and skin testing: 1990-2001. J Allergy Clin Immunol. 2004;113:1129-36.

17. Canadian Agency for Drugs and Technologies in Health (CADTH). Guidelines for the Economic Evaluation of Health Technologies: Canada (4th Edition). 2017;

18. Blume SW, Yeomans K, Allen-Ramey F, Smith N, Kim H, Lockey RF, et al. Administration and Burden of Subcutaneous Immunotherapy for Allergic Rhinitis in U.S. and Canadian Clinical Practice. J Manag Care Spec Pharm. 2015;21:98290.

19. Ontario Public Drug Programs [Internet]. Available from: http://www.health.gov.on.ca/en/public/programs/drugs/. Accessed Oct 06, 2020

20. PMPRB. (2019). Dispensing Fee Policies in Public Drug Plans, 2017/18. [Internet]. Available from: PMPRB. (2019). Dispensing Fee Policies in Public Drug Plans, 2017/18. http://www.pmprb-cepmb.gc.ca/view.asp?ccid=1308. Accessed Oct 06, 2020

21. Régie de l'assurance maladie du Québec, RAMQ. (Effective September 30, 2020) [Internet]. Available from: http://www.ramq.gouv.qc.ca/en/Pages/home.aspx. Accessed Oct06, 2020

22. Dispensing fee Quebec - data on file/personal communication.

23. Ontario Schedule of Benefits (effective April1, 2020) [Internet]. Available from: http://www.health.gov.on.ca/en/pro/programs/ohip/sob/physserv/sob_master20200306.pdf. Accessed Sep09, 2020

24. Medecins Omnipracticiens (June 2020) [Internet]. Available from: https://www.ramq.gouv.qc.ca/SiteCollectionDocuments/professionnels/manuels/syra/medecins-omnipraticiens/100facturation-omnipraticiens/manuel-omnipraticiens-remuneration-acte-RFP.pdf

25. 2020 full time average hourly rate (Ontario) [Internet]. Available from: https://www.livingin-canada.com/salaries-forregistered-nurses.html. Accessed Oct 06, 2020

26. 2018 full time average hourly rate (Montreal-Quebec). Adjusted to 2020. [Internet]. Available from: https://www.livingincanada.com/salaries-for-registered-nurses.html. Accessed Oct 06, 2020

27. Statistics Canada, average hourly wages employees by selected characteristics and occupation [Internet]. Available from: http://www.statcan.gc.ca/tables-tableaux/sum-som/I01/cst01/labr69a-eng.htm. Accessed Oct 06, 2020

28. Government of Canada 2020 Reasonable Allowance Rates [Internet]. Available from: https://www.canada.ca/en/revenue-agency/services/tax/businesses/topics/payroll/benefitsallowances/automobile/automobile-motor-vehicle-allowances/reasonable-kilometre-allowance.html. Accessed Oct 06, 2020

29. Hankin CS, Cox L. Allergy immunotherapy: what is the evidence for cost saving? Curr Opin Allergy Clin Immunol. 2014;14:363-70.

30. Sondermann N, Shah-Hosseini K, Henkel K, Schwalfenberg A, Mösges R. Erfolgsfaktoren der Adherence bei Hyposensibilisierung. Allergologie. 2011;34:441-6.

31. Damm K, Volk J, Horn A, Allam J-P, Troensegaard-Petersen N, Serup-Hansen N, et al. Patient preferences in allergy immunotherapy (AIT) in Germany - a discrete-choice-experiment. Health Econ Rev. 2016;6:32.

32. Ellis AK, Boursiquot J, Carr S, Graham F, Masse M-S. Patient and physician perceptions of seasonal allergic rhinitis and allergen immunotherapy: a parallel physician patient survey. Allergy Asthma Clin Immunol Off J Can Soc Allergy Clin Immunol [Internet]. 2020 [cited 2020 Nov 19];16. Available from:

https://www.ncbi.nlm.nih.gov/pmc/articles/PMC7035743/

Page 13/14 
33. Biedermann T, Kuna P, Panzner P, Valovirta E, Andersson M, de Blay F, et al. The SQ tree SLIT-tablet is highly effective and well tolerated: Results from a randomized, double-blind, placebo-controlled phase III trial. J Allergy Clin Immunol. 2019;143:1058-1066.e6.

34. Björstad Å, Cardell L-O, Hahn-Pedersen J, Svärd M. A Cost-Minimisation Analysis Comparing Sublingual Immunotherapy to Subcutaneous Immunotherapy for the Treatment of House Dust Mite Allergy in a Swedish Setting. Clin Drug Investig. 2017;37:541-9.

35. Ellis AK, Gagnon R, Hammerby E, Lau A. Sublingual immunotherapy tablet for the treatment of house dust mite allergic rhinitis in Canada: an alternative to minimize treatment costs? Allergy Asthma Clin Immunol Off J Can Soc Allergy Clin Immunol. 2019;15:27.

36. Rønborg S, Johnsen C, Theilgaard S, Winther A, Hahn-Pedersen J, Andreasen J, et al. Cost-minimisation analysis of sublingual immunotherapy versus subcutaneous immunotherapy for house dust mite respiratory allergic disease in Denmark. J Med Econ. 2016;19:1-17.

\section{Figures}

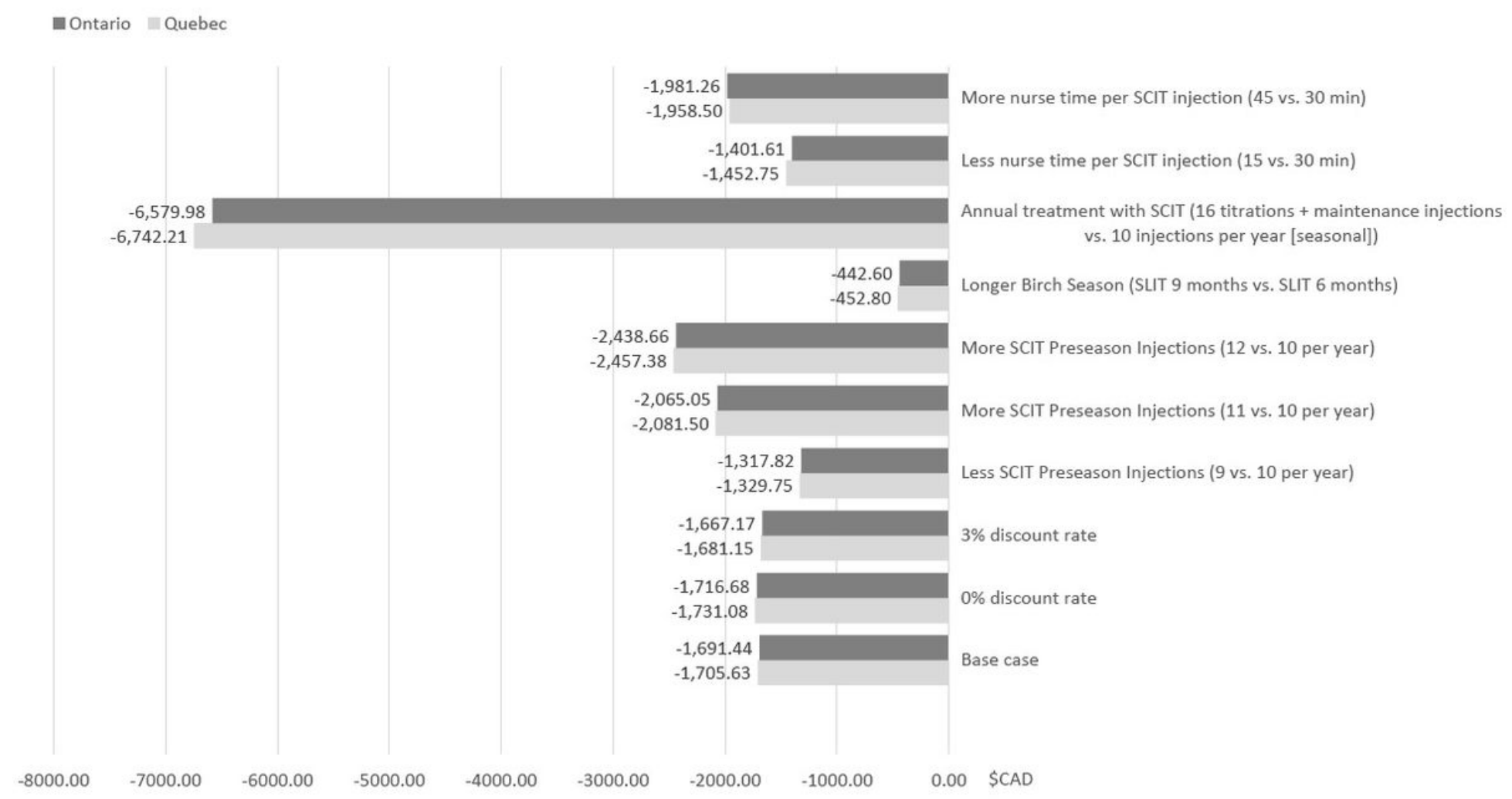

\section{Figure 1}

Scenario analyses: potential total savings of SQ Tree SLIT-tablets vs. Tree Pollen SCIT Potential total savings according to total costs. Total cost of three-year's treatment are discounted with $1.5 \%$ as described in methods, except for the scenario analyses " $0 \%$ discount rate" and " $3 \%$ discount rate" where the parameter discount rate was changed to $0 \%$ or $3 \%$, respectively. Abbreviations: SQ Tree SLIT standardized quality birch pollen sublingual immunotherapy, Tree Pollen SCIT Tree Pollen subcutaneous immunotherapy 